\title{
Impact of different tillage practices on soil physical properties, nitrate leaching and yield attributes of maize (Zea mays L.)
}

\author{
Shahbaz Khan ${ }^{1,2^{*}}$ Aqeel Shah ${ }^{3}$, Muhammad Nawaz $^{4}$, Mohsin Khan ${ }^{5}$
}

${ }^{1}$ Department of Agronomy, University of Agriculture, Faisalabad, Pakistan. ${ }^{2}$ Department of Plant and Soil Sciences, Institute of Agricultural Biosciences, Oklahoma State University, 3210 Sam Noble Parkway, Ardmore, OK73401. ${ }^{3}$ Institute of Soil and Environmental Sciences, University of Agriculture, Faisalabad, Pakistan. ${ }^{4}$ Department of Agronomy, College of Agriculture, BZU, Bahadur Campus Layyah, Pakistan. ${ }^{5}$ Department of Agricultural Sciences, Allama Iqbal Open University, Pakistan. *Corresponding author: shahbaz.khan@okstate.edu

\begin{abstract}
Tillage, undoubtedly, is one of the most crucial practices to ameliorate crop productivity and maintain soil health. A field experiment was conducted at research farms; Institute of Soil and Environmental Sciences, University of Agriculture, Faisalabad, Pakistan to examine how soil properties and maize crop respond to different tillage strategies (minimum, conventional and deep tillage). Randomized complete block design (RCBD) was finalized for the experiment with three repeats. Maximum total biomass production and grain yield were recorded in case of deep tillage practices. Conventional tillage not only improved leaf area index but also harvest. Minimum tillage minimized the leaching of nutrients especially nitrates. Soil bulk density $\left(\mathrm{Mg} \mathrm{m}^{-3}\right)$, particle density, soil organic carbon $\left(\mathrm{g} \mathrm{kg}^{-1}\right)$, infiltration rate $\left(\mathrm{mm} \mathrm{hr}^{-1}\right)$, percent porosity (\%) and soil saturated hydraulic conductivity $\left(\mathrm{mm} \mathrm{hr}^{-1}\right)$ got affected by different tillage practices. Minimum tillage is suggested to avoid leaching losses of nutrients, this loss reduces the crop productivity.
\end{abstract}

Keywords: Tillage, maize, leaching, nitrates, soil properties 


\section{Introduction}

Maize, after wheat and rice, is $3^{\text {rd }}$ most important cereal crop. It plays a decisive role in agriculture-based economy of the country. It has vital nutritional value: maize seeds contain many by-products like glucose, fatty acid, amino acid etc along with $72 \%$ starch, $10 \%$ protein, $4.8 \%$ oil and $8.5 \%$ fiber (M.F.A; Ministry of Food and Agriculture, 2014-15).

Tillage, one of the most important practices in agriculture, performed primarily to mix the soil with organic residues and fertilizer, to loose the upper layer of soil, to check weeds and to create a suitable seedbed for germination and plant growth (Rasmussen 1999). Soil physical and biological characteristics are influenced by tillage practice, which in turn lead to alter plant growth and yield (Wasaya et al., 2011, Rashidi and Keshavarzpour 2007).

Atkinson et al., (2007) reported that nitrogen, as a macro nutrient, has an essential role in plant nutrition and also acts as one of the most important yield limiting plant nutrient for crop production around the globe. The mineralization of soil organic matter releases nitrogen $(\mathrm{N})$ that is readily available to the plant. The $\mathrm{NH}_{4}$ - and $\mathrm{NO}_{3}$ - are two important $\mathrm{N}$ forms available to plants. Along with tillage, amount of irrigation, type of fertilizer and amount and time of application are also key factors that affect plant growth and soil environment.

Different soil management regimes such as abandonment, resulted in greater levels of soil microbial biomass than did Cropping, but similar levels of enzyme activity were observed under both regimes. The Fallow regime gave significantly lower soil organic carbon levels and enzyme activities than did Cropping. Within the Cropping system, the treatments containning nitrogen and phophorus significantly improved SOC, $\mathrm{N}$ and $\mathrm{P}$ levels and also increased microbial biomass and enzyme activity relative to the control. In general, the highest values of the tested soil parameters were observed under the M2NPK treatment. With the exception of invertase, the activity of all soil enzymes tested correlated significantly with SOC and microbial biomass. It was concluded that the use of fertilization regimes involving applying organic material in conjunction with NPK fertilizers should be encouraged in order to maintain or improve the chemical and biological properties of the tested loess soil and to thereby increase its productivity (Zhang et al., 2015).

Some nitrogenous fertilizers such as ammonium nitrate and urea have a high mobility potential and may undergo leaching. Also, the excessive use of nitrogenous fertilizers in agriculture has resulted in losses in the form of their derivatives and leaching of fertilizers below the root zone that created problems by contaminating groundwater (Wierenga 1977). Nitrate, passing through macro pores, which serve as flow passage for water, can move into the soil with the infiltrate water. The enhanced water movement through soil macro pores in the profile increases the potential of soluble nitrates movement under no tillage scenario (Ahmad et al., 2009). Ground water pollution, due to nitrate $\left(\mathrm{NO}_{3}^{-}\right)$leaching, causes serious problems concerning human health and the environment in many developing as well as developed countries (Benbi et al., 1991, Carman 1997, Wilson et al., 1999). Nitrate leaching, a naturally occurring process, occurs when nitrates leave the soil in drainage water. Nitrate, being soluble and mobile, is not problematic when it is present in the root-zone, but when it goes beyond root zone or into the ground water and other fresh water bodies it causes environmental pollution. Drinking nitrate $\left(\mathrm{NO}_{3}^{-}\right)$contaminated water can result in various diseases in the human and animals especially in infants like methemoglobinemia commonly known as blue baby syndrome (Ray 2011). 
Aikins and Afuakwa (2010) searched the factors which affect nitrate movement in soil profile; it included soil physical properties (especially soil texture and structure) irrigation water, soil type, method and time of nitrogen fertilizer application and the management practices. They further reported, after the experimentation, that favorable soil conditions and higher amount of nutrients availability to the plant does happen due to conventionally tilled soil and it may also lead to vigorous crop growth which is the result of rapid decomposition of organic source of $\mathrm{N}$ in deep soil layer. Mehdi et al., (1999) and Sainju and Singh (2001) concluded that the application of tillage practice in crop production system is important for the plant growth as it affects soil environmental components. It can also have its influence on the $\mathrm{N}$ availability and $\mathrm{N}$ pool status for maintaining proper nutrient levels in the soil environment system. The effect of tillage practices particularly on $\mathrm{N}$, for the crop production, is therefore critical for the production of sustainable crops. The integration practices including appropriate $\mathrm{N}$ management and tillage practices, for sustainable crop production, thus presents a significant challenge.

Therefore, currently, different tillage techniques are being used without evaluating their effects on physical, chemical and mechanical properties of soil. So there is a substantial interest and emphasis on the shift to conservation and no-tillage methods. Thus, this study was conducted to determine the effect of different tillage strategies on the movement of nitrate in the soil profile and to check response of some selected physical and mechanical properties of soil (moisture content, bulk density and penetration resistance). Hence, the objectives of this study were to estimate the effect of minimum tillage, conventional tillage and deep tillage strategies on the movement of nitrate $\left(\mathrm{NO}_{3}^{-}\right)$in the soil profile and how some selected physical properties of soil (bulk density, par- ticle density, porosity, infiltration rate, and soil saturated hydraulic conductivity) respond towards tillage.

\section{Materials and Methods}

A field experiment was conducted at research farms; Institute of Soil and Environmental Sciences, University of Agriculture, Faisalabad $\left(31.25^{\circ} \mathrm{N}, 73.09^{\circ} \mathrm{E}\right)$, Pakistan during the year 2011-12 to examine the effect of different tillage strategies (minimum, conventional and deep tillage) on soil properties and crop growth with treatment plan (Table 1). The climate of Faisalabad region is subtropical with an average precipitation of about $200 \mathrm{~mm}$. The experiment was laid out in randomized complete block design (RCBD) having three repeats with net plot size of $7.38 \mathrm{~m} \times 8.53 \mathrm{~m}$.

The maize variety Pioneer $30 \mathrm{Y} 87$ was cultivated as a test crop, with hand drill, keeping row to row $(\mathrm{R} \times \mathrm{R})$ and plant to plant $(\mathrm{P} \times \mathrm{P})$ distances of 30 " and 9" respectively having seed rate of $25 \mathrm{~kg} \mathrm{ha}^{-1}$. Recommended doses of N, P and K (195, 140 and $\left.105 \mathrm{~kg} \mathrm{ha}^{-1}\right)$ were applied. Doses of nitrogen, phosphorous and potassium were applied using urea, di-ammonium phosphate and sulphate of potash (SOP). All the doses of phosphorous and potassium were given at the time of sowing while nitrogen was applied in three splits. Six (6) irrigations of 4 " each were applied to the maize crop. To avoid the competition by weeds and keep the crop free from insects, pests and diseases, plant protection measures were carried out uniformly.

Prior to experimentation, soil samples were collected and analyzed for physical and chemical properties (EC, $\mathrm{pH}$, organic carbon, soil bulk density, soil saturated hydraulic conductivity and infiltration rate) using standard methods and procedures (Table 2). Data collected, for all the parameters, were analyzed statistically using fisher's analysis of variance technique and least significant (LSD) test, at 5\% probability level, was applied to compare the treatments' means (Steel et al., 1997). 
Table 1. Treatment planning

\begin{tabular}{llc}
\hline & Treatment & Description \\
\hline $\mathrm{T}_{1}$ & Minimum Tillage (MT) & $(2$ ploughing +2 planking $)$ \\
$\mathrm{T}_{2}$ & Conventional Tillage ( CT $)$ & $(1$ disc +2 planking +2 ploughing $)$ \\
$\mathrm{T}_{3}$ & Deep Tillage ( DT) & $(1 \mathrm{MBP}+2$ planking +2 ploughing $)$ \\
\hline
\end{tabular}

Table 2. Physico-chemical properties of experimental soil

\begin{tabular}{lc}
\hline Determination & Values \\
\hline Chemical analysis & 7.83 \\
$\mathrm{pH}$ & 1.73 \\
$\mathrm{EC}\left(\mathrm{dS} \mathrm{m}^{-1}\right)$ & 1.43 \\
Soil bulk density $\left(\mathrm{Mg} \mathrm{m}^{-3}\right)$ & 45.40 \\
Total Porosity $(\%)$ & 25.40 \\
Soil Infiltration Rate $\left(\mathrm{mm} \mathrm{hr}^{-1}\right)$ & 53.07 \\
Soil Hydraulic Conductivity $\left(\mathrm{mm} \mathrm{hr}^{-1}\right)$ & 0.52 \\
Total Nitrogen $\left(\mathrm{mg} \mathrm{kg}^{-1}\right)$ & 9.46 \\
Available phosphorus $\left(\mathrm{mg} \mathrm{kg}^{-1}\right)$ & 114.08 \\
Available Potassium $\left(\mathrm{mg} \mathrm{kg}^{-1}\right)$ & 2.54 \\
Soil Organic Carbon $\left(\mathrm{g} \mathrm{kg}^{-1}\right)$ & \\
Physical analysis & 46 \\
Sand (\%) & 30 \\
Silt (\%) & 25 \\
Clay (\%) & Sandy clay loam \\
Textural Class
\end{tabular}

\subsection{Agronomic parameters}

Total grain yield (ton ha $\mathrm{h}^{-1}$ ), total plant biomass (ton $\left.\mathrm{ha}^{-1}\right)$ and harvest index (\%) were measured at maturity after harvesting. Leaf area index (LAI) was also recorded. Plant samples were also collected from each plot according to standard procedure.

\subsection{Soil parameters}

Soil bulk density $\left(\mathrm{Mg} \mathrm{m}^{-3}\right)$, particle density, soil organic carbon $\left(\mathrm{g} \mathrm{kg}^{-1}\right)$, infiltration rate $\left(\mathrm{mm} \mathrm{hr}^{-1}\right)$, percent porosity $(\%)$, soil saturated hydraulic conductivity $(\mathrm{mm}$ $\left.\mathrm{hr}^{-1}\right)$ and nitrate concentration $\left(\mathrm{mg} \mathrm{kg}^{-1}\right)$ were measured after harvesting of the crop. After harvesting of the crop, soil samples were also collected from each plot following standard procedures. Soil bulk density was determined by core method as described by Blake and Hartge (1986) while soil particle density was determined using pycnometer method. Soil organic carbon was determined up to 1 $\mathrm{m}$ depth following the method described by Ryan et al., (2001). Infiltration rate was measured with a double ring infiltrometer (Klute 1986). Soil porosity was calculated using the following formula;

Percent porosity $(\phi)=1-($ Bulk density / particle density) $\times 100$ 
Soil saturated hydraulic conductivity was measured by Guelph permeameter (Model $2800 \mathrm{KI}$ ), taking three steady-state readings.

\subsection{Nitrates measurement}

Nitrate-N was measured by a spectrophotometric method (using chromo tropic acid). Bouyoucos hydrometer method was applied to examine percentage of sand, silt, and clay. After obtaining the extract from saturated soil paste with the help of vacuum pump ECe was measured using a digital Jenway electrical conductivity meter (Dellavalle 1992a). Soil $\mathrm{pH}$ was recorded with a digital $\mathrm{pH}$ meter, after making a standard soil saturated paste and standardizing $\mathrm{pH}$ meter with 4.0 and $9.2 \mathrm{pH}$ buffer solutions (Dellavalle 1992a).

\section{Results}

\subsection{Total grain yield (ton $\mathrm{ha}^{-1}$ )}

After harvesting of maize, total grain yield was recorded and highest grain yield ( 7.25 ton $\left.\mathrm{ha}^{-1}\right)$ was obtained from those plots where deep tillage practices were done followed by conventional tillage practices. Minimum grain yield (6.45 ton $\mathrm{ha}^{-1}$ ) was noted where minimum tillage was practiced. However, regarding deep tillage grain yield was increased $10.99 \%$ in deep tillage as compared to minimum tillage. Hence, table 3 shows the results are significant.

\subsection{Total plant biomass (ton $\mathrm{ha}^{-1}$ )}

After harvesting of maize, total plant biomass was noted and highest total plant biomass (39.82 ton ha-1) was obtained from those plots where the deep tillage practices were performed that was followed by conventional tillage practices in maize. Lowest total plant biomass (35.30 ton ha-1) was recorded from minimum tillage practiced plots. Deep tillage practice improved the total biomass up to $11.35 \%$ than minimum tillage practice (Table 3).

\subsection{Harvest index (\%)}

Highest harvest index (18.73\%) was recorded from those plots where the conventional tillage practices were done followed by minimum tillage treatment in maize. Lowest harvest index (18.18\%) was recorded from deep tillage practiced plots. As regards conventional tillage practices which improved the harvest index $2.93 \%$ than deep tillage (Table 3 ).

\subsection{Leaf area index (LAI)}

During maize growth period the highest value for leaf area index (7.18) was obtained from those plots where the conventional tillage practices were exercised followed by deep tillage practices while lowest leaf area index (6.47) was recorded from minimum tillage practiced plots. Leaf area index was enhanced up to $9.89 \%$ by deep tillage practices as compared to minimum tillage (Table 3).

\subsection{Soil bulk density $\left(\mathrm{Mg} \mathrm{m}^{-3}\right)$}

After harvesting of maize crop, soil bulk density was recorded and highest values for bulk density $(\mathrm{Mg}$ $\mathrm{m}^{-3}$ ) was recorded $\left(1.48 \mathrm{Mg} \mathrm{m}^{-3}\right)$ from those plots where T1 (minimum tillage) practices were done followed by $\mathrm{T} 3$ (deep tillage) treatment. Lowest bulk density $\left(1.40 \mathrm{Mg} \mathrm{m}^{-3}\right)$ was recorded from T2 (conventional tillage) practiced plots. So $\mathrm{T} 2$ treatment represented increased bulk density up to $5.40 \%$ than T1 treatment (Table 4). 
Table 3. Effect of different tillage strategies on agronomic parameters of maize

\begin{tabular}{lcccc}
\hline Treatment & $\begin{array}{c}\text { Grain yield } \\
\left(\text { ton } \mathrm{ha}^{-1}\right)\end{array}$ & $\begin{array}{c}\text { Plant biomass } \\
\left(\text { ton ha }^{-1}\right)\end{array}$ & $\begin{array}{c}\text { Harvest index } \\
(\%)\end{array}$ & $\begin{array}{c}\text { Leaf area index } \\
(\mathrm{LAI})\end{array}$ \\
\hline Minimum Tillage & $6444.8 \mathrm{~B}$ & $35300 \mathrm{C}$ & $18.256 \mathrm{~B}$ & $6.4667 \mathrm{C}$ \\
Conventional Tillage & $7224.8 \mathrm{~A}$ & $38566 \mathrm{~B}$ & $18.732 \mathrm{~A}$ & $7.1767 \mathrm{~A}$ \\
Deep Tillage & $7241.2 \mathrm{~A}$ & $39822 \mathrm{~A}$ & $18.183 \mathrm{~B}$ & $6.8767 \mathrm{~B}$ \\
LSD $(0.05)$ & 164.74 & 180.96 & 0.3497 & 0.1739 \\
\hline
\end{tabular}

Table 4. Effect of different tillage strategies on soil properties

\begin{tabular}{|c|c|c|c|c|c|c|}
\hline Treatment & $\begin{array}{l}\text { Soil bulk } \\
\text { density } \\
\left(\mathrm{Mg} \mathrm{m}^{-3}\right)\end{array}$ & $\begin{array}{c}\text { Particle } \\
\text { density } \\
\left(\mathrm{Mg} \mathrm{m}^{-3}\right)\end{array}$ & $\begin{array}{c}\text { Soil organic } \\
\text { carbon } \\
\left(\mathrm{g} \mathrm{kg}^{-1}\right)\end{array}$ & $\begin{array}{l}\text { Infiltration } \\
\text { rate } \\
\left(\mathrm{mm} \mathrm{hr}^{-1}\right)\end{array}$ & $\begin{array}{c}\text { Percent } \\
\text { porosity } \\
(\%)\end{array}$ & $\begin{array}{c}\text { Soil saturated } \\
\text { hydraulic } \\
\text { conductivity } \\
\left(\mathrm{mm} \mathrm{hr}^{-1}\right)\end{array}$ \\
\hline Minimum Tillage & $1.28 \mathrm{a}$ & 2.64 & 3.57 & 22.95 & $43.943 \mathrm{~b}$ & $48.95 \mathrm{~B}$ \\
\hline Conventional Tillage & $1.40 \mathrm{~b}$ & 2.63 & 3.56 & 25.35 & $46.773 \mathrm{a}$ & $57.71 \mathrm{~A}$ \\
\hline Deep Tillage & $1.41 \mathrm{~b}$ & 2.63 & 3.57 & 25.27 & $46.39 \mathrm{a}$ & $57.92 \mathrm{~A}$ \\
\hline $\operatorname{LSD}(0.05)$ & 0.0507 & NS & NS & NS & 1.3531 & 4.4836 \\
\hline
\end{tabular}

\subsection{Particle density}

After harvesting of maize crop, soil particle density was noted and highest value for particle density $(\mathrm{Mg}$ $\mathrm{m}-3)$ was measured $\left(2.64 \mathrm{Mg} \mathrm{m}^{-3}\right)$ from those plots where minimum tillage practices were done. Conventional tillage and deep tillage treatments in maize showed similar results $\left(2.63 \mathrm{Mg} \mathrm{m}^{-3}\right)$. While minimum tillage improved particle density up to $0.37 \%$ than conventional and deep tillage treatments (Table 4).

\subsection{Soil organic carbon $\left(g \mathrm{~kg}^{-1}\right)$}

After harvesting of maize crop, soil samples were analyzed for determination of soil organic carbon. Highest values for soil organic carbon were (3.57) recorded from those plots where the minimum tillage and deep tillage treatment practices were done. While the lowest value of soil organic carbon were (3.56) recorded from plots where conventional tillage practices were done. As regards minimum and deep tillage treatments soil organic carbon was improved $0.28 \%$ then conventional tillage. Therefore, Table 4 shows treatments results are non-significant.

\subsection{Infiltration rate $\left(\mathrm{mm} \mathrm{hr}^{-1}\right)$}

After harvesting of maize crop, soil infiltration rate was noted and greatest values for infiltration rate were recorded $\left(25.35 \mathrm{~mm} \mathrm{hour}^{-1}\right)$ from those plots where the conventional tillage practices were exercised followed by deep tillage treatment. Lowest infiltration rate $\left(22.95 \mathrm{~mm} \mathrm{hour}^{-1}\right)$ was recorded from minimum tillage practiced plots. So the conventional treatment showed an increase of $9.46 \%$ for infiltration rate than minimum treatment. Therefore, Table 4 shows nonsignificant results. 


\subsection{Percent porosity (\%)}

After harvesting of maize crop, percent porosity was recorded and greatest values of percent porosity $(\phi)$ were recorded (46.77) from those plots where the conventional tillage practices were done followed by deep tillage. Minimum percent porosity $(\phi)$ (43.94) was recorded from minimum tillage practiced plots. So the conventional tillage treatment showed $6.05 \%$ more percent porosity than minimum treatment. Therefore, Table 4 shows significant results.

\subsection{Soil saturated hydraulic conductivity $\left(\mathrm{mm} \mathrm{hr}^{-1}\right)$}

After harvesting of maize crop soil saturated hydraulic conductivity was measured. Maximum soil saturated hydraulic conductivity ( $\mathrm{mm}$ hour ${ }^{-1}$ ) was recorded (57.92) from those plots where the deep tillage practices were done followed by conventional tillage treatment. Minimum soil saturated hydraulic conductivity (48.95) was recorded from minimum tillage practiced plots. So the deep tillage treatment showed $15.48 \%$ more soil saturated hydraulic conductivity than minimum treatment. Table 4 shows the results are significant.

\subsection{Nitrate $\left(\mathrm{NO}_{3}^{-}\right)$concentration $\left(\mathrm{mg} \mathrm{kg}^{-1}\right)$ in soil at $0-25 \mathrm{~cm}$ soil depth before sowing and after harvesting of maize crop}

Soil samples were collected at the depth of $0-25 \mathrm{~cm}$ after application of tillage treatment and before sowing of the maize crop. Nitrate $\left(\mathrm{NO}_{3}-\right)$ concentration was statistically non-significant however 3.61, 3.63 and $3.65 \mathrm{mg} \mathrm{kg}^{-1}$ were recorded in minimum tillage, conventional tillage and deep tillage respectively (Figure 1). After harvesting of maize, nitrate $\left(\mathrm{NO}_{3}\right.$ ) concentration in soil at the depth of $0-25 \mathrm{~cm} \mathrm{had}$ highest value $\left(5.63 \mathrm{mg} \mathrm{kg}^{-1}\right)$. From plots where the conventional tillage practices were done as followed by deep tillage treatment $\left(5.42 \mathrm{mg} \mathrm{kg}^{-1}\right)$ and lowest nitrate (NO3-) in soil (5.38 $\left.\mathrm{mg} \mathrm{kg}^{-1}\right)$ was recorded from those plots where minimum tillage practice was done (Figure 2). As regards conventional tillage treatment which is $4.44 \%$ higher in nitrate $\left(\mathrm{NO}_{3}^{-}\right)$concentration than minimum tillage. Figure 2 shows that there is variation in the nitrate concentration at the depth of $0-25 \mathrm{~cm}$ but statistically results are non-significant.

3.12. Nitrate $\left(\mathrm{NO}_{3}-\right)$ concentration $\left(\mathrm{mg} \mathrm{kg}^{-1}\right)$ in soil at $25-50 \mathrm{~cm}$ soil depth before sowing and after harvesting of maize crop

Before sowing of maize, nitrate $\left(\mathrm{NO}_{3}^{-}\right)$concentration was statistically non-significant at the depth of $25-50 \mathrm{~cm}$, however 3.92, 4.05 and $4.32 \mathrm{mg} \mathrm{kg}^{-1}$ were recorded in minimum tillage, conventional tillage and deep tillage respectively (Figure 1). After harvesting of crop, the highest nitrate $\left(\mathrm{NO}_{3}{ }^{-}\right)$concentration was ( $7.09 \mathrm{mg} \mathrm{kg}^{-1}$ ) recorded at the depth of $25-50 \mathrm{~cm}$ in soil from plots where minimum tillage was done followed by plots having conventional tillage practices. Deep tillage treatment plots showed lowest nitrate $\left(\mathrm{NO}_{3}-\right)$ concentration. As minimum tillage treatment showed more nitrate $\left(\mathrm{NO}_{3}^{-}\right)$concentration up to $17.34 \%$ than deep tillage. Therefore, the Fgure 2 shows the results are significant.

3.13. Nitrate $\left(\mathrm{NO}_{3}^{-}\right)$concentration $\left(\mathrm{mg} \mathrm{kg}^{-1}\right)$ in soil at $50-75 \mathrm{~cm}$ soil depth before sowing and after harvesting of maize crop

Before sowing of maize, nitrate $\left(\mathrm{NO}_{3}^{-}\right)$concentration at the depth of 50-75 $\mathrm{cm}$ was recorded highest (7.37 $\mathrm{mg} \mathrm{kg}^{-1}$ ) in plots where minimum tillage practices were done followed by plots getting deep tillage practice $\left(6.92 \mathrm{mg} \mathrm{kg}^{-1}\right)$. Minimum nitrate $\left(\mathrm{NO}_{3}^{-}\right)$ concentration was $\left(6.76 \mathrm{mg} \mathrm{kg}^{-1}\right)$ recorded from plots 
where conventional tillage practice was done. Figure 1 shows that nitrate concentrations are statistically significant under different tillage practices. After harvesting the crop, at the depth of $50-75 \mathrm{~cm}$ in soil the highest nitrate $\left(\mathrm{NO}_{3}^{-}\right)$concentration was $(10.37 \mathrm{mg}$ $\mathrm{kg}^{-1}$ ) recorded in those plots where the minimum tillage practices $\left(9.94 \mathrm{mg} \mathrm{kg}^{-1}\right)$ was done followed by deep t illage treatment practiced plots. Lowest value for the nitrate $\left(\mathrm{NO}_{3}{ }^{-}\right)$concentration was $(9.13 \mathrm{mg}$ $\mathrm{kg}^{-1}$ ) recorded from plots where the conventional tillage practice was done in maize. As minimum tillage which showed higher nitrate concentration up to $11.95 \%$ then conventional tillage treatment. Therefore, Fgure 1 shows that nitrate concentrations are statistically significant under different tillage practices at the depth of 50-75 cm.

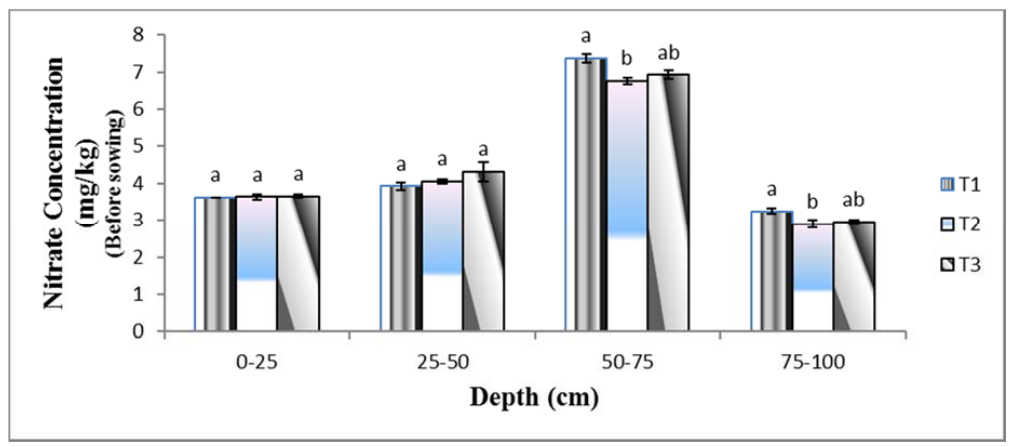

Figure 1. Effect of different tillage strategies on nitrate $\left(\mathrm{NO}_{3}-\right)$ concentration in different depths of the soil before sowing of maize (Zea mays L.) crop.

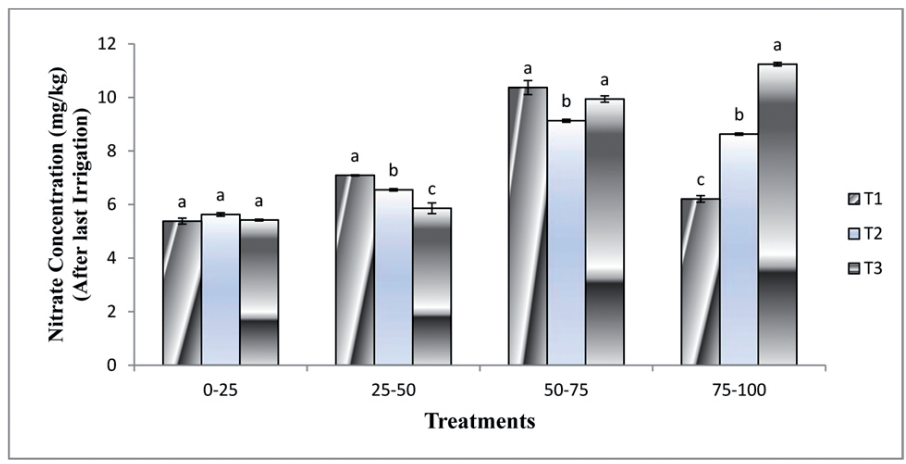

Figure 2. Effect of different tillage strategies on nitrate $\left(\mathrm{NO}_{3}-\right)$ concentration in different depths of the soil after $6^{\text {th }}$ irrigation during maize (Zea mays L.) crop. 
3.14. Nitrate $\left(\mathrm{NO}_{3}^{-}\right)$concentration $\left(\mathrm{mg} \mathrm{kg}^{-1}\right)$ in soil at $75-100 \mathrm{~cm}$ soil depth before sowing and after harvesting of maize crop

Before sowing of maize, maximum nitrate $\left(\mathrm{NO}_{3}{ }^{-}\right)$ concentration $\left(3.25 \mathrm{mg} \mathrm{kg}^{-1}\right)$ was recorded at the depth of 75-100 cm, in plots where minimum tillage practices were done followed by deep tillage treatment practiced plots $\left(2.95 \mathrm{mg} \mathrm{kg}^{-1}\right)$. The lowest value for the nitrate $\left(\mathrm{NO}_{3}^{-}\right)$concentration was $\left(2.89 \mathrm{mg} \mathrm{kg}^{-1}\right)$ recorded from those plots where conventional tillage practices were done. Figure 1 shows that nitrate concentrations are statistically significant under different tillage practices.

At the depth of 75-100 cm, maximum nitrate $\left(\mathrm{NO}_{3}^{-}\right)$concentration was (11.24 $\left.\mathrm{mg} \mathrm{kg}^{-1}\right)$ recorded in plots where deep tillage practices were done followed by conventional tillage treatment practiced $\left(8.63 \mathrm{mg} \mathrm{kg}^{-1}\right)$ plots. Lowest value for the nitrate $\left(\mathrm{NO}_{3}^{-}\right)$concentration was $(6.21 \mathrm{mg}$ $\mathrm{kg}^{-1}$ ) recorded from plots where minimum tillage was done in maize. Deep tillage showed $44.39 \%$ more concentration of nitrate $\left(\mathrm{NO}_{3}-\right)$ than minimum tillage treatment. As figure 2 shows that nitrate concentrations are statistically significant under different tillage practices. These results summarized in Table 5

Table 5. Effect of different tillage strategies Nitrate $\left(\mathrm{NO}_{3}-\right)$ concentration $\left(\mathrm{mg} \mathrm{kg}^{-1}\right)$ in soil at different soil depth after harvesting of maize crop

\begin{tabular}{lcccc}
\hline Treatment & $0-25(\mathrm{~cm})$ & $25-50(\mathrm{~cm})$ & $50-75(\mathrm{~cm})$ & $75-100(\mathrm{~cm})$ \\
\hline Minimum Tillage & 5.38 & $7.09 \mathrm{~A}$ & $10.37 \mathrm{~A}$ & $6.21 \mathrm{C}$ \\
Conventional Tillage & 5.42 & $6.55 \mathrm{~B}$ & $9.13 \mathrm{~B}$ & $8.63 \mathrm{~B}$ \\
Deep Tillage & 5.42 & $5.86 \mathrm{C}$ & $9.94 \mathrm{~A}$ & $11.24 \mathrm{~A}$ \\
LSD $(0.05)$ & NS & 0.3909 & 0.7996 & 0.2585 \\
\hline
\end{tabular}

\section{Discussion}

Gomma et al., (2002) also found similar results. They conducted field experiments and studied maize grain yield under different tillage systems and highest grain yield was obtained by conventional tillage treatment. Tillage practice improved the availability of nutrients and water for efficient uptake that ultimately resulted in high grain yield. The results are also in line with the findings of Gul et al., (2009). They conducted an experiment and their results were similar with the present study that significantly highest biological yield was obtained by practicing conventional tillage as compared to no tillage or reduced tillage and minimum tillage practices. This may be due to availability of nutrients and more production of root hairs because of well tilth soil favorable for root proliferation and it may also have facilitated nutrient uptake. Habtegebrial et al., (2007) also found similar results. They reported that various nitrogen sources and different tillage practices have significant influence on grain yield of maize. Higher yields can be achieved by conventional and deep tillage practices as compared to reduced tillage. Establishment of crop is better and conventional tillage might have contributed to higher grain yield and higher leaf area in these plots as compared to reduced tillage plots. It is also reported that tillage practices are also involved in retention of moisture in the soil and residues management on the soil surface, which ultimately cause increase in maize yield. Habtegebrial 
et al., (2007) reported that various nitrogen sources and different tillage practices have significant influence on biological yield of maize and ultimately affect leaf area of crop. Conventional tillage might have contributed to higher grain yield, higher leaf area and better establishment of crop in these plots. The results are similar to the findings of Khan et al., (1999). They studied the effect of different tillage practices on soil physical properties and concluded that conventional tillage affected soil bulk density and also caused decrease in soil penetration resistance which resulted in increased drainage and nitrate leaching. Jabro et al., (2010) also found similar results; they studied that deep tillage resulted in lowering soil penetration resistance by manipulating and loosening of the deeper soil layer and ultimately resulted in more absorption of mobile nutrients from deeper soil depth.

Bulk density and soil strength were relatively lower in ridge sowing plots as compared to seed drill and seed broadcasting plots. The results are similar to the findings of Bahadar et al., (2007) who studied the effect of tillage on soil organic carbon and reported after an experiment that generally it is believed that tillage practices are the primary cause of losing soil organic matter owing to soil disturbance. This problem can be solved by changing preferences as tillage known as reduced and minimum tillage having less destructive effects as compared to the conventional one. Agostini et al., (2012) evaluated bulk density, penetration resistance, hydraulic conductivity, plant population, surface root distribution, aboveground dry matter accumulation, aboveground total nitrogen accumulation and corn yield. Their results show that high stocking rate and FM increased penetration resistance. On the other hand, shallow tillage decreased penetration resistance and bulk density and increased hydraulic conductivity. Corn yield was higher under shallow tillage than under no till, and under high stocking rate than under the other grazing strategies. Total nitrogen accumulation was higher under high stocking rate than under the rest of grazing strategies. Rational grazing management and use of tillage systems on resilient soils could have prevented soil physical properties be affected beyond critical thresholds.

Basamba et al., (2006) found similar results who concluded after an experiment that soil organic soil and total C, N and P were generally better under no-till as compared to minimum-tilled soils. While P fractions were also generally higher under no-till treatments. Results from this study indicated that rotational systems (maize-soybean green manure and maizepastures) improved the soil conditions to implement no-till or minimum tillage systems. Aulakh and Malhi (2005) also studied same results that soluble nutrients move into the soil profile through infiltered water into the macro pores and in case of no tillage practice there is a little disturbance in soil structure and macro pores come in contact with soil surface. Rashidi and Keshavarzpour (2007) also studied same results; they reported that conventional tillage also has impact by producing loose and finer soil structure as compared to no-tillage and conservation tillage systems and results in decreased water movement into the soil profile thus decreased nitrate leaching. Memon et al., (2007) conducted an experiment and it was found that soil moisture content was higher in ridge sowing method as compared to other sowing methods.

According to the Aulakh and Malhi (2005) soluble nutrients move into soil profile through infiltration of water into the macro pores. In case of no tillage practice there is a little disturbance in soil structure and macro pores come in contact with soil surface. Thus, these macro pores provide a path for water flow to full depth into the soil profile so nitrate leaching is more in case of no tillage as compared to other tillage practices which disturb the soil structure and ultimately water flow is hindered. Kanwar et al., (1985) concluded that there is $100 \%$ more water movement into the 
soil profile in no tillage as compared to conventional tillage which resulted in slightly greater concentration of nitrate leached beyond root zone in no tillage as compared with conventional tillage.

Brunel-Saldias et al., (2016) reported that the soil had low water holding capacity in the profile due to the low water retention at the permanent wilting point (matric water potential lower than -1.500 $\mathrm{kPa}$ ), associated with a high bulk density and clay content. The conservation tillage systems (ZT and ZTS), were similar in the parameters of fast drainage pores (FDP), aggregate stability index, airflow, and rest coefficient compared with CT. However, the volume of pores with diameters between 10-50 $\mu \mathrm{m}$ was higher in ZTS in a $24 \%$ and $13 \%$, compared with ZT and CT, respectively. In addition, the root development increased significantly in ZTS. In conclusion, the physical condition of the compacted soil was improved by the zero tillage system with subsoiling, which promoted a better root system in the first horizons in highly compacted soils. Bahadar et al., (2007) reported after an experiment that generally it is believed that tillage practices are the primary cause of losing soil organic matter which is due to soil disturbance. This problem can be solved by changing preferences as tillage known as reduced and minimum tillage having less destructive effects as compared to conventional tillage.

Halvorson et al., (2001) also studied same results that soil tillage practice is one of the most important factors which has its influence on crop yield, soil physical properties and ultimately on $\mathrm{NO}_{3}$ - movement into the soil profile and nitrogen uptake. Benbi et al., (1991) studied that tillage systems can affect many soil properties, which ultimately alter the soil environment and consequently impact on root growth and distribution and crop yield also.

\section{Conclusion}

Tillage is an important factor which plays a decisive role in crop productivity, availability of nutrients and water. It affects soil physical and, up to some extent chemical properties. Minimum tillage enhances the availability of nutrients to the plants. It, not only, improves different soil properties like soil bulk density, particle density, soil organic carbon, infiltration rate, percent porosity and soil saturated hydraulic conductivity but also is considered a phenomenon more appropriate to minimize leaching of nutrients along with water. Leachates are tantamount to be pollutants of underground water because they deteriorate the quality of underground water which ultimately affects the plant as well as human life.

\section{References}

Agostini, M.A., Studdert, G.A., Martino, S.S., Costa, J.L., Balbuena, R.H., Ressia, J.M., Mendivil, G.O., Lázaro, L. 2012. Crop residue grazing and tillage systems effects on soil physical properties and corn (Zea mays L.) performance. Journal of Soil Science and Plant Nutrition. 12(2), 271-282.

Ahmad, I., Iqbal, M., Ahmad, B., Ahmad, G., Shah, N.H. 2009. Maize yield, plant tissue and residual soil $\mathrm{N}$ as affected by nitrogen management and tillage systems. J. Agric. Biol. Sci. 1, 19-29.

Aikins, S.H.M., Afuakwa, J.J. 2010. Effect of four different tillage practices on cowpea performance. World J. Agric. Sci. 6 (6), 644-651.

Atkinson, H.S., Sparkes, D.L., Mooney, S.J. 2007. Using selected soil physical properties of seedbeds to predict crop establishment. Soil and tillage Res. 97, 218-228. 
Aulakh, M.S., Malhi, S.S. 2005. Interactions of nitrogen with other nutrients and water: effect on crop yield and quality, nutrient use efficiency, carbon sequestration, and environmental pollution. Adv. Agron. 86, 341-409.

Bahadar, K.M., Arif, M., Khan, M.A. 2007. Effect of tillage and zinc application methods on weeds and yield of maize. Pak. J. Bot. 39, 1583-1591.

Basamba, T.A., Barrios, E., zquita, E.A., Rao, I.M., Singh, B.R. 2006. Tillage effects on maize yield in a Colombian savanna oxisol: Soil organic matter and P fractions. Soil \& Tillage Res. 91, 131-142.

Benbi, D.K., Biswas, C.R., Kalkat, J.S. 1991. Nitrate distribution and accumulation in anUstochrept soil profile in a long-term fertilizer experiment. Fert. Res. 28, 173-177.

Brunel-Saldias, N., Martínez, I., Seguel, O., Ovalle, C., Acevedo, E. 2016. Structural characterization of a compacted alfisol under different tillage systems. J. Soil Sci. Plant Nutr. 16(3). http://dx.doi. org/10.4067/S0718-95162016005000050.

Carman, K. 1997. Effect of different tillage systems on soil properties and wheat yield in Middle Anatolia. Soil and tillage Res. 40, 201-207.

Dellavalle, N.B. 1992. Determination of soil-paste $\mathrm{pH}$ and conductivity of saturation extract. In handbook on reference methods for soil analysis. Soil and plant anal. coun. inc. Athens, GA, Pp. 40-43.

Gomma, M.R., Gibbons, A.K., Ei, D. 2002. Maize grain yield as influenced by nitrogen levels with and without organic manures under different tillage systems. Annals Agric. Sci. 40, 723-739.

Gul, B., Marwat, K.B., Hassan, G., Khan, A., Hashim, S., Khan, I.A. 2009. Impact of tillage, plant population and mulches on biological yield of maize. Pak. J. Bot. 41, 2243-2249.
Habtegebrial, K., Singh, B.R., Haile, M. 2007. Impact of tillage and nitrogen fertilization on yield, nitrogen use efficiency of tef Eragrostis, Trotter and soil properties. Soil \& Tillage Res. 94, 55-63.

Halvorson, A.D., Wienhold, B.J., Black, A.L. 2001. Tillage and nitrogen fertilization influence grain and soil nitrogen in an annual cropping system. Agron. Journal. 93, 836-841.

Harmmel, J.E. 1989. Long term tillage and crop rotation effects on bulk density and soil impedance in northern Idaho. Soil Sci. Soc. Ame. Journal. 53, 1515-1519.

Jabro, J.D., Stevens, W.B., Iversen, W.M., Evans, R.G. 2010. Tillage depth effects on soil physical properties, sugarbeet yield and sugarbeet quality. Communic. Soil Sci. Plant Anal. 41, 908-916.

Kanwar, R.S., Baker, J.L., Laflen, J.M. 1985. Nitrate movement through the soil profile inrelation to tillage system and fertilizer application method. Trans. ASAE 28, 1802-1807.

Khan, F.U.H., Tahir, A.R., Yule, I.J. 1999. Impact of different tillage practices and temporal factor on soil moisture content and soil bulk density. International Journal Agri. Bio. 3, 163-166.

Klute, A. 1986. Method of soil analysis. Part 1 Soil Sci. Soc. Am. Pub. Madison, WI, USA.

Ministry of Food and Agriculture (M.F.A.). 2015. Islamabad Pakistan.

Mehdi, B.B., Madramootoo, C.A., Mehuys, G.R. 1999. Yield and nitrogen content of corn under different tillage practices. Agron. J. 91, 631-636.

Rashidi, M., Keshavarzpour, F. 2007. Effect of different tillage methods on grain yield and yield components of maize (Zea mays L.). International Journal of Agriculture and Bio. 2, 274-277.

Rasmussen, K.J. 1999. Impact of ploughless soil tillage on yield and soil quality: A Scandinavian review. Soil and Tillage Research. 53, 3-14. 
Ray, C. 2011. Managing nitrate problems for domestic wells in irrigated alluvial, aquifers. J. Environ. Qual. 45, 675-687.

Sainju, U.M., Singh, B.P. 2001. Tillage, cover crop, and kill-planting date effects on corn yield and soil nitrogen. Agron. J. 93, 878-868.

Steel, R.G.D., Torrie, J.H., Deekey, D.A. 1997. Principles and Procedures of Statistics. A Biometrical Approach. 3rd Ed. Mc Graw Hill Book. Int. Co. New York, pp: 400-428.

Wasaya, A., Tahir, M., Manaf, A., Ahmed, M., Kaleem, S., Ahmad, I. 2011. Improving maize productivity through tillage and nitrogen management. Afr. J. Biotech. 10, 19025-19034.
Wierenga, P.J. 1977. Solute distribution profiles computed with steady-state and transient water movement models. Soil Sci. Soc. Ame. J. 41, 10501055 .

Wilson, W.S., Ball, A.S., Hinton, R.H. 1999. Managing risks of nitrates to humans and the environment. The Royal Society of Chemistry, Cambridge, UK. pp. 348.

Zhang, S., Li, H., Yang, X., Sun, B. 2015. Effects of soil management regimes on biochemical properties of a loess soil. J. Soil Sci. Plant Nutr. 15(3). http://dx.doi.org/10.4067/S071895162015005000048 